\title{
PENGARUH BERKUMUR SARI BUAH ANGGUR MERAH BERBAGAI KONSENTRASI DAN CHLORHEXIDINE 0,12\% TERHADAP INDEKS PLAK
}

\author{
Henny Eka Putri ${ }^{\star}$, Prima Agusmawanti ${ }^{* *}$, Ade Ismail ${ }^{* *}$
}

\begin{tabular}{c}
\hline Keywords: \\
Juice of red grapes, \\
Chlorhexidine, \\
Plaque Index \\
\hline
\end{tabular}

\section{ABSTRACT}

Background: Plaque plays an important role in causing caries and periodontal problems. Plaque control should be done chemically in an effort to reduce the accumulation of plaque in the oral cavity. Juice of red grapes (Vitis vinifera) has a chemical compound as an antibacterial catechins and tannins. The purpose of this study is to determine the effect of rinsing with red grape juice with different concentrations of chlorhexidine and $0.12 \%$ during the 7 day study of the reduction of plaque index. Method: This study is quasi-experimental study which was conducted on 25 students Aisyiyah Orphanage. After Scaling and toothbrush cleaning, each sample rinsed with $10 \mathrm{ml}$ of solution 3 times a day has been accepted in accordance with the treatment without taking action toothbrush for 7 days. Result: The mean plaque index in the treatment group began to experience a gradual decline in the fourth day until the seventh day of the study. From the results of Mann Whitney test analysis found significant differences between the various groups of SBA and chlorhexidine $0.12 \%$ concentration with distilled water on the fourth to the seventh day of the study. But between the SBA $100 \%$ with chlorhexidine $0.12 \%$ there is no significant difference.

Conclusion: This can be concluded that rinsing with red grape juice with a concentration of $50 \%, 75 \% 100 \%$ and chlorhexidine $0.12 \%$ has efficacy in reducing the plaque index. $100 \%$ SBA group is a group of the most effective concentration.

\section{PENDAHULUAN}

Kebersihan gigi dan mulut akan mempengaruhi kualitas hidup seseorang yaitu fungsi bicara, pengunyahan dan rasa percaya diri ${ }^{1}$. Indikator melihat kebersihan gigi dan mulut adalah ada tidaknya deposit organik seperti pelikel, materi alba, sisa makanan dan plak gigi karena dengan banyaknya plak yang melekat pada permukaan gigi mengartikan bahwa buruknya seseorang dalam menjaga kebersihan gigi dan mulutnya ${ }^{2}$. Plak berperan penting dalam menyebabkan masalah kesehatan gigi dan mulut. Akumulasi plak pada rongga mulut akan inflamasi yang menyerang jaringan lunak dan jaringan pendukung gigi yang disebabkan karena adanya mikroorganisme ${ }^{3}$.

Salah satu upaya menghilangkan dan mencegah adanya penumpukan plak didalam rongga mulut pada permukaan gigi dapat dilakukan dengan menggunakan obat kumur. Di dalam obat kumur terkandung senyawa antiseptik yang dapat menghambat pertumbuhan dan perkembangan bakteri di rongga mulut, sehingga dapat menghambat pembentukan plak dan mencegah terjadinya penyakit periodontal ${ }^{4}$.

Penggunaan bahan alami untuk kesehatan gigi dan mulut telah banyak digunakan karena memiliki efek terapeutik yaitu mengendalikan plak, gingivitis, halitosis dan mencegah kerusakan gigi ${ }^{5}$. Buah Anggur merah (Vitis Vinifera) merupakan bahan alami berupa buah yang kaya senyawa kimia yakni catechin dan tannin yang memiliki sifat antibakteri yang dapat menghambat pembentukan plak di rongga mulut ${ }^{6}$.

${ }^{*}$ Program Pendidikan Dokter Gigi UNISSULA, ${ }^{* *}$ FKG Universitas Islam Sultan Agung Korespondesi: Henny Eka Putri (hennyekaputri@gmail.com) 
Penelitian ini bertujuan mengetahui pengaruh berkumur dengan sari buah anggur merah (Vitis Vinifera) berbagai konsentrasi terhadap penurunan indeks plak.

\section{METODE PENELITIAN}

Jenis penelitian ini adalah eksperimen semu atau uji klinis dengan menggunakan rancangan post test control group design untuk mengetahui pengaruh berkumur sari buah anggur merah (vitis vinifera) konsentrasi $50 \%, 75 \%, 100 \%$ dan chlorhexidine $0,12 \%$ dilakukan di Panti Asuhan Aisyiyah, Pondok Indraprasta, Semarang.

Dalam pemilihan sampel dilakukan secara simple random sampling dan dibagi menjadi 5 kelompok, masingmasing kelompok terdiri dari 5 sampel. Sampel di pilih berdasarkan kriteri inklusi yaitu Usia santri 13 - 20 tahun, terdapat karies yang telah di tambal, tidak dalam perawatan ortodontik atau pemakaian protesa gigi, tidak terdapat penyakit mulut, seperti penyakit periodontal, gingivitis, stomatitis ,susunan gigi crowded derajat ringan, tidak dicurigai memiliki riwayat penyakit sistemik, tidak sedang merokok dan tidak sedang menggunakan obatobatan antibiotik.

Pembuatan sari buah anggur dibuat tiga kali sehari, dibuat dengan cara sebanyak kira $300 \mathrm{mg}$ setiap kali pembuatan. Buah anggur dicuci menggunakan air terlebih dahulu, buah yang telah bersih dimasukkan ke dalam juicer untuk dilakukan pengambilan sari buah anggur. Sebelum mendapat perlakuan semua sampel dilakukan tindakan scaling menggunakan ultrasonic scaler oleh mahasiswa co-ass RSIGM Sultan Agung lalu dilakukan sikat gigi bersama guna menyamakan kondisi awal. Sampel diberikan pengarahan cara berkumur, lama berkumur, dan teknik berkumur.

Pengukuran indeks plak diukur dengan menggunakan personal hygiene performance (PHP) atau indeks PHP yang diperkenalkan oleh Posdhadley dan Haley. Permukaan gigi yang di periksa adalah permukaan buccal gigi 16 dan 26 , permukaan lingual gigi 36 dan 46 , dan permukaan labial gigi 11 dan 41 .

Dari hasil penelitian yang diperoleh dilakukan diuji normalitas dengan Saphiro-Wilk dan uji homogenitas dengan Levene's Test. Oleh karena sebaran data antar kelompok tidak normal akan tetapi variasi data homogen sehingga selanjutnya dilakukan uji non parametrik Kruskal-Wallis yang dilanjutkan dengan uji Mann-Whitney.

\section{HASIL PENELITIAN}

Hasil penelitian menunjukkan bahwa semua kelompok perlakuan mengalami peningkatan indeks plak, akan tetapi penurunan rata rata indeks plak mulai berangsur angsur turun pada hari keempat hingga hari ketujuh, kecuali pada kelompok aquadest yang terus mengalami peningkatan indeks plak. Grafik penurunan rata-rata indeks plak hari pertama hingga hari ketujuh dapat di lihat pada grafik 1.

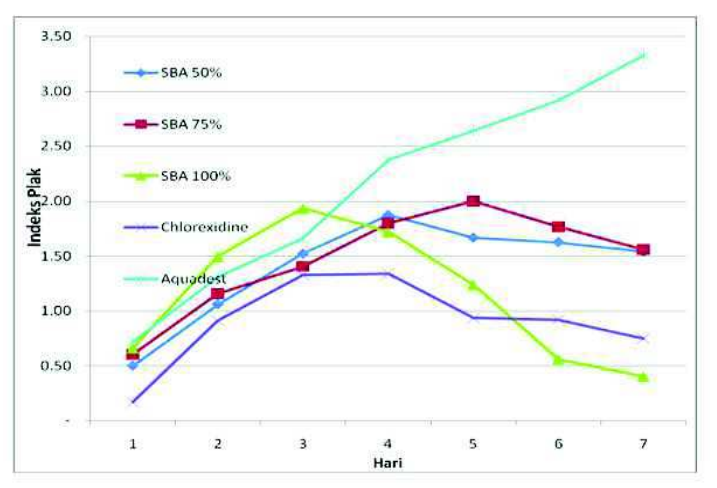

Grafik 1 : Rerata indeks plak dari hari ke-1 hingga hari ke-7

Pada (grafik 1) rata-rata indeks plak antar kelompok mengalami penurunan, penurunan tertinggi terdapat pada kelompok dengan berkumur sari buah anggur merah konsentrasi $100 \%$, diikuti kelompok berkumur chlorhexidine, kelompok sari buah anggur konsentrasi 


\begin{tabular}{|c|c|c|c|c|c|c|c|}
\hline & HARI 1 & HARI 2 & HARI 3 & HARI 4 & HARI 5 & HARI 6 & HARI 7 \\
\hline & $\begin{array}{c}\text { P.Shapiro } \\
\text { Wilk }\end{array}$ & $\begin{array}{c}\text { P.Shapiro } \\
\text { Wilk }\end{array}$ & $\begin{array}{c}\text { P. Shapiro } \\
\text { Wilk }\end{array}$ & $\begin{array}{c}\text { P.Shapiro } \\
\text { Wilk }\end{array}$ & $\begin{array}{c}\text { P. Shapiro } \\
\text { Wilk }\end{array}$ & $\begin{array}{c}\text { P. Shapiro } \\
\text { Wilk }\end{array}$ & $\begin{array}{c}\text { P.Shapiro } \\
\text { Wilk }\end{array}$ \\
\hline SBA $50 \%$ & $1.000^{*}$ & $0.375^{*}$ & $0.633^{*}$ & $0.781^{*}$ & $0.027 *$ & $0.114 *$ & $0.474^{*}$ \\
\hline SBA $75 \%$ & $0.628 *$ & $0.953 *$ & $0.257 *$ & $0.037 * *$ & $0.890 *$ & $0.333 *$ & $0.872 *$ \\
\hline SBA $100 \%$ & $0.556 *$ & $0.720 *$ & $0.685 *$ & $0.814 *$ & $0.134 *$ & $0.114 *$ & $0.032 * *$ \\
\hline Chlorexidine & $0.155^{*}$ & $0.011 * *$ & 0.998 * & $0.147 *$ & $0.753 *$ & $0.641 *$ & $0.267 *$ \\
\hline Aquadest & $0.458 *$ & $0.998 *$ & $0.329 *$ & $0.006 * *$ & $0.033 * *$ & $0.028 * *$ & $0.832 *$ \\
\hline P Levene Test & $0.486^{\#}$ & $0.191^{\#}$ & $0.301^{\#}$ & $0.264^{\#}$ & $0.144^{\#}$ & $0.639^{\#}$ & $0.580^{\#}$ \\
\hline
\end{tabular}

Tabel 1. Hasil uji normalitas dan homogenitas

$50 \%$ dan $75 \%$ dan kelompok aquadest.

Dari uji normalitas Shapiro-Wilk dan homogenitas (tabel 1) didapatkan sebaran data tidak normal akan tetapi homogen menyebabkan uji paramaterik oneway annova tidak dapat dilakukan sehingga dipilih uji non- parametrik uji kruskal wallis pada semua data kemudian dilanjutkan uji mann whitney guna mengetahui perbedaan antara masingmasing konsentrasi.

\begin{tabular}{lc}
\hline \multicolumn{1}{c}{ Kelompok waktu } & Sig $(\mathrm{p})$ \\
\hline Hari 1 & 0.306 \\
Hari 2 & 0.595 \\
Hari 3 & 0.625 \\
Hari 4 & 0.010 \\
Hari 5 & 0.001 \\
Hari 6 & 0.002 \\
Hari 7 & 0.002 \\
\hline
\end{tabular}

Tabel 2. Hasil uji Kruskall Wallis Indeks Plak
Pada (tabel 2) menjelaskan hasil uji Kruskall wallis indeks plak pada kelompok hari 1, 2 dan 3 menunjukkan nilai signifikansi ( $p>0,05$ ) menunjukkan bahwa tidak terdapat perbedaan signifikan antar kelompok perlakuan pada hari 1, 2 dan 3. Pada hari 4, 5, 6 dan 7 menunjukkan nilai signifikasi yang kurang dari 0,05 (p $<0,05)$ yang berarti terdapat perbedaan pada setiap kelompok perlakuan sehingga perlu dilakukan uji lanjut menggunakan uji mann whitney.

Hasil uji lanjut (tabel 3) diketahui nilai signifikan $(p<0,05)$ terdapat antara kelompok aquadest dengan kelompok perlakuan sari buah anggur konsentrasi $50 \%, 75 \%, 100 \%$ dan chlorhexidine yang menunjukkan bahwa terdapat perbedaan yang bermakna. Pada kelompok sari buah anggur konsentrasi 100\% dengan chlorhexidine memiliki efek yang sama dengan ditunjukkan nilai signifikansi

\begin{tabular}{llllll}
\hline \multicolumn{2}{c}{$\begin{array}{c}\text { Pasangan } \\
\text { Kelompok perlakuan }\end{array}$} & Hari 4 & \multicolumn{1}{c}{$\begin{array}{c}\text { Hari } 5 \\
\text { Probability }\end{array}$} & \multicolumn{1}{c}{ Hari 6 } \\
\hline SBA 50\% & SBA 75\% & $0.690^{* *}$ & $0.548^{* *}$ & $0.841^{* *}$ & $0.841^{* *}$ \\
& SBA 100\% & $0.690^{* *}$ & $0.151^{* *}$ & $0.056^{* *}$ & $0.056^{* *}$ \\
& Chlorexidine & $0.095^{* *}$ & $0.095^{* *}$ & $0.095^{* *}$ & $0.151^{* *}$ \\
& Aquadest & $0.056^{* *}$ & $0.008^{*}$ & $0.008^{*}$ & $0.008^{*}$ \\
SBA 75\% & SBA 100\% & $0.690^{* *}$ & $0.016^{*}$ & $0.016^{*}$ & $0.016^{*}$ \\
& Chlorexidine & $0.056^{* *}$ & $0.008^{*}$ & $0.032^{*}$ & $0.151^{* *}$ \\
& Aquadest & $0.008^{*}$ & $0.008^{*}$ & $0.008^{*}$ & $0.008^{*}$ \\
SBA 100\% & Chlorexidine & $0.151^{* *}$ & $0.310^{* *}$ & $0.310^{* *}$ & $0.421^{* *}$ \\
& Aquadest & $0.016^{*}$ & $0.008^{*}$ & $0.008^{*}$ & $0.008^{*}$ \\
Chlorexidine & Aquadest & $0.008^{*}$ & $0.008^{*}$ & $0.008^{*}$ & $0.008^{*}$ \\
\hline
\end{tabular}

Tabel 3. Hasil Uji Lanjut (uji mann whitney) kelompok hari 4, 5, 6 dan 7 
sebesar $p=0,371(p>0,05)$.

\section{DISKUSI}

Rata-rata indeks plak sari buah anggur merah konsentrasi 100\% merupakan rata-rata indeks plak terendah hingga hari ketujuh yaitu sebesar 0,40. Efek menghambat pembentukan plak dari sari buah anggur dapat terjadi karena didalam buah anggur merah terdapat senyawa yaitu senyawa flavonoid berupa catechin dan senyawa polifenol berupa tannin ${ }^{7}$.

Catechin merupakan senyawa flavonoid yang dapat menghambat pembentukan plak pada permukaan gigi dengan cara menghambat enzim glucosiltransferase yang merupakan suatu senyawa yang mengkatalisis sukrosa menjadi bahan adesin berupa glukan oleh bakteri streptococcus mutans ${ }^{8}$. Kedua dengan cara mendenaturasi protein bakteri karena fenol yang terkandung didalam katekin merupakan senyawa toksik yang mengakibatkan struktur tiga dimensi protein terbuka kemudian stuktur menjadi acak sehingga deret asam amino protein tetap utuh akan tetapi aktivitas biologis bakteri menjadi rusak ${ }^{9}$.

Senyawa polifenol berupa tannin bekerja menghambat plak pada gigi dengan cara menghambat enzim glucosiltranferase dan mengganggu membran sel bakteri sehingga membran sel bakteri menjadi lisis ${ }^{10}$. Senyawa antibakteri yaitu catechin dan tannin yang terkandung dalam buah anggur merah menyebabkan bahan adesin seperti glukan tidak terbentuk sehingga terjadi penurunan perlekatan bakteri dan penurunan indeks plak yang menempel pada permukaan gigi juga mengalami penurunan ${ }^{8}$.

Sifat antibakteri buah anggur merah dapat mengurangi akumulasi plak pada gigi dengan cara mengurangi pembentukan formasi acquired pelicel di dalam saliva yaitu menghambat enzim glucosiltranferase ${ }^{11}$, enzim yang memegang peranan penting dari bakteri streptococcus mutans di dalam plak.

Dengan terhambatnya enzim tersebut maka pembentukan plak yang menempel pada permukaan gigi akan gagal ${ }^{12}$.

Kelompok sari buah anggur merah konsentrasi $50 \%$ dan $75 \%$ menunjukkan hasil bahwa efektifitas sari buah anggur merah $50 \%$ lebih tinggi daripada konsentrasi $75 \%$. Hal ini dapat terjadi karena selama penelitian berjalan terdapat variabel yang tidak dapat di kendalikan yaitu adanya ketidakpatuhan sampel dalam berkumur dan sampel yang melakukan pembersihan gigi sehingga menurunkan skor plak.

Efektifitas sari buah anggur merah konsentrasi $100 \%$ setara dengan efektifitas chlorhexidine $0,12 \%$ dalam menghambat pembentukan plak. Chlorhexidine merupakan derivate bisquanid cationic molekul dengan aktivitas antimikroba spectrum luas. Sifat dari agen ini tergantung pada konsentrasi nya, dapat bersifat bakterisid atau bakteriostatik yang memiliki aksi potensi pada bakteri gram positif dan gram negatif ${ }^{13}$. Sesuai dengan penelitian Prijantojo (1996) bahwa penggunaan obat kumur chlorhexidine selama 7 hari dapat menurunkan indeks plak dengan hasil signifikansi $(p<0,05)$ pada hari ketiga dan dapat mengurangi radang pada gingiva pada hari kelima penelitian ${ }^{14}$.

Dari hasil uji statisktik penggunaan sari buah anggur merah berbagai konsentrasi di dapatkan $(p<0,05)$ di bandingkan dengan kelompok aquadest, hal ini menunjukkan bahwa sari buah anggur merah dapat menurunkan indeks plak secara bermakna. Hipotesis dalam penelitian ini dapat diterima yaitu ada pengaruh berkumur sari buah anggur merah (vitis vinifera) dengan konsentrasi $50 \%, 75 \%, 100 \%$ dan Chlorhexidine $0,12 \%$ terhadap penurunan indeks plak.

\section{KESIMPULAN}

Berdasarkan hasil penelitian ini dapat disimpulkan bahwa :

1. Berkumur sari buah anggur merah 
konsentrasi $50 \%, 75 \%$, 100\% dan chlorhexidine $0,12 \%$ berpengaruh dalam menurunkan indeks plak selama 7 hari penelitian.

2. Penurunan indeks plak di setiap kelompok perlakuan mulai mengalami menurun pada hari keempat hingga hari ketujuh penelitian.

3. Berkumur sari buah anggur merah konsentrasi $100 \%$ lebih efektif menurunkan indeks plak dibandingkan dengan sari buah anggur merah konsentrasi $50 \%$ dan $75 \%$.

4. Berkumur sari buah anggur merah $100 \%$ memiliki efek sama terhadap chlorexidine dalam menurunkan indeks plak.

5. Sari buah anggur merah $100 \%$ paling efektif dalam menurunkan indeks plak hingga hari ketujuh penelitian dengan nilai rata-rata indeks plak sebesar 0,40 .

\section{DAFTAR PUSTAKA}

1. Putri MH, Herijulianti Eliza, Nurjannah Neneng. IImu Pencegahan Penyakit Jaringan Keras dan Jaringan Pendukung Gigi. Jakarta: EGC Penerbit Buku Kedokteran; 2010: Hal. 54-64; 93-98; 104-109

2. Quirynen dkk, in Carranza EA., Newman MG: Clinical periodontology. 9th Ed. W.B.Saunders. Philadelphia.2006. pg 76,134

3. Peter dkk,. In.Carranza E.A dan M.G.Newman. Clinical Periodontology. 9th Ed. Philadelphia: W.B. Saunders. 2004

4. Agusmawanti, P,. Perbandingan Daya Anti Bakteri Kumur Rebusan Daun Gambir (Uncaria Gambir) dengan Chlorehexidine 0,2 \% terhadap Jumlah Koloni Bakteri Saliva. FKG Universitas Islam Sultan Agung. Majalah IImiah Universitas Sultan Agung. 2011. Vol. XLIX No.123

5. Nagappan N., John Joseph. Antimicrobial
Efficacy of Herbal and Chlorhexidine Mouth Rinse A systematic Review. IOSR Journal Of Dental and Medical Sciences. 2012. Vol 2, Issue 4. Page 1-6

6. Nisak ,Nasichatun,. Pengaruh pemberian jus buah anggur (vitis vinifera) terhadap pembentukan plak gigi. Artikel publikasi ilmiah. Fakultas Kedokteran. Institutional Repository (UNDIP-IR). Universitas Diponegoro. Semarang. 2005

7. Tilong, Adi D,. Cegah Kanker Dengan Anggur. Jogjakarta. Diva Press. 2012. Hal .7-9, 31- 51

8. Oktavianti, Ridzki Almeria, Rusdiana Elly, Rahardjo Pambudi,. Efektifitas Menyikat Gigi Dengan Menggunakan Pasta Gigi Anggur/Vitis Vinifera Terhadap Penurunan Plak Pemakai Peranti Ortodonti Cekat. Orthodontic dental Journal. 2012. Vol 3 No.1: hal 37-42

9. Amiati,R.D,. Pengaruh pasta gigi dengan kandungan buah anggur terhadap pembentukan plak gigi. Artikel Publikasi IImiah. Fakultas Kedokteran. Institutional Repository (UNDIP-IR). Universitas Diponegoro, Semarang. 2011

10. Natarini, Febrina.Widhi. Perbandingan Efek Antibakteri Jus Anggur Merah (vitis vinifera) pada berbagai konsentrasi terhadap streptococcus mutans. Artikel Publikasi IImiah. Fakultas Kedokteran. Institutional Repository (UNDIP-IR). Universitas Diponegoro. 2007

11. Wu, Christine D. Grape Products And Oral Health. The journal of nutrition. 2009. Pg 18181823

12. Xia, En Qin dkk,. Biological Activities of polyphenol From Grapes. International Journal of Molecular Sciences. 2010. pg 622-637

13. Haq, W.M dkk. Efficacy of Antiplaque Moutwashes A five Day Clinical trial. General Dentistry. Liaquat College of Medicine \& Dentistry. Pakistan. 2010. P. 11-15

14. Prijantojo. Penurunan Radang Gingiva dengan Pemakaian Larutan 0,2\% Chlorhexidine Sebagai Obat Kumur. Majalah Cermin Dunia Kedokteran, 1996b.Hal. 113:33-36 